\title{
The Employers' Responsibility to the Community
}

\author{
By SAM A. Lewisohn \\ Of Adolph Lewisohn \& Sons, New York City
}

$I^{\mathrm{N}}$ $\mathrm{N}$ any discussion of the employer's ${ }^{1}$ relation to the community, local or national, we must be careful to keep in mind that he is part and parcel of the community. His relation to it is not to something outside himself, but to something of which he is an essential component. A socially healthy community, local and national, reacts upon his well-being as much as it does upon the well-being of any other member of the community. I emphasize this because there is a tendency in some quarters to regard the employer, particularly in his relation to the local community, as a commanding officer of an army of occupation. His proper rôle is that of an influential citizen and neighbor-a citizen and neighbor possessed of great power for good or evil.

This influence and power comes because under the capitalistic system executive control over production is decentralized, and at least to a large degree is disassociated from our political system. In order to preserve the initiative and adventuring instinct of the individual business man, it has been deemed advisable, particularly in this country, not to impinge upon his sphere of power. This decentralization has its obvious advantages in efficiency, and disadvantages to those who believe in carrying democratic tenets to their logical conclusion. But it is un-

1 When I speak of employer, I refer either to the hierarchy of executives in a corporation or to a proprietor owner. Of course, in the case of a proprietor owner the relation to the local community is apt to be more intimate than that of a large corporation, but the resident manager of a large corporation can and often does act as a substitute for the proprietor owner. necessary to discuss the pros and cons here.

\section{Public Service}

Now with influence and power come opportunity and responsibility -in this case, of helping the particular community to help itself. I have said opportunity advisedly, for effective public service is always an opportunity. I have said responsibility, for it is a definite duty which cannot be shifted to anyone else; a duty which should be regarded not as a by-product of the business adventure, but as an integral part of that adventure. For a really modern-minded employer realizes that making money is only one part of his activity, and that his position logically includes the responsibility of developing and leading both his internal organization and that portion of the community with which he comes into contact. It is the old story that "charity begins at home," only charity is, to say the least, an inappropriate term. As Mr. Glenn Frank puts it, "Statesmanship in business has come to be adjudged worthier of a real man's mettle than philanthropy outside business." I am thinking of the story related by a liberal English employer. He tried to convert a fellow employer to his point of view in relation to these matters. The answer was "Well, you've got your hobbies and I have mine." Employers must be made to realize that attention to these matters is not a fad but a natural element in their careers as employers. There is little to be said for the theory advanced by negligent employers on one hand, or by some radical doctrinaires on the 
other, that a policy of "hands off" everything which concerns employees after factory hours is desirable or possible.

\section{Building a Community}

It is unnecessary to go into a detailed statement of the specific problems which face each employer. The main thing is the spirit in which the problem is approached. If the particular industry is located in a community that is already well developed the task of the employer is relatively easy. His relation to it is then that of any other influential citizen, that of helping to develop what has already been established and of acting as a leader. On the other hand, where an industry is located in an isolated region, the employer has the task of building a healthy community from the ground up.

To suggest some of the concrete duties there is first, that of seeing that in some manner proper housing facilities are developed; second, to see that some center, such as a club or Y.M.C.A., is provided for social life, and to do everything else that is possible to promote a healthy social life; third, to see that educational facilities are adequate, including facilities for adult education, particularly in connection with the teaching of English to the foreign-born; fourtl, to see that the town is provided with adequate municipal facilities such as streets, sewers, etc.; fifth, in some cases to provide coöperative stores.

In any community developed or undeveloped the situation requires a particularly high degree of tact, for it is very easy to have a desire to serve the community appear to the community like a desire to patronize and dominate. If there is any one thing an employer must remember it is that just because of his position of power and influence he must be tactful. If I were to add a commandment particularly applicable to employers it would be "Thou must be tactful."

Some employers take a paternalistic Lady-Bountiful point of view. Often it is the very same employer that talks about the necessity of a "sturdy individualism." I have in mind one very well meant experiment in this direction. The company in question bought up the particular town in which they were operating and built quite a remarkable and beautiful town from an architectural point of view; but there was something about the way in which the town was conducted which made every individual in that town feel that he was a minion of the powers that be. For all their trouble instead of a wellsatisfied community the employers had created a dissatisfied community. If employers would only exercise a little imagination and cultivate a sense of humor they would steer clear of assuming the rôle of feudal lords. Let them put themselves in the position of the men under them; let them think how they would feel if their positions were reversed; let them think of their youth and their resentment at any interference with their independence, and they will realize how delicate are their relations to the community.

In other cases it is not so much a matter of patronization as that of bad judgment. A Y.M. C.A. was built in a community in which several employers were located and in which the majority of the employees were Roman Catholics. Naturally it was not well patronized. An industrial club in this instance would have been much better. In this particular instance the lack of judgment was self-evident. I cite it to indicate that each situation must be studied separately. This is in no way to disparage the work of the Industrial Y. M. C. A. In fact it has a distinct 
advantage - that of not being under company control and of being democratically administered. A Y.M.C.A. is therefore usually much more effective than a company-built club, particularly in a town in which only one industry is located. For no matter how much a company tries to keep its hands off, there is always the suspicion of company control.

\section{Housing Faotuities}

The question of housing, of course, is a very difficult one. Company-owned houses have their obvious disadvantages. On the other hand, to leave the problem of housing to outside influences is often obviously ill-advised, and to ask an employee to own his own house is often an injustice for various reasons. Where it is feasible some scheme of copartnership housing should be installed so that the employees have the benefit on the one hand of the feeling of ownership and at the same time know that their ownership is of such an elastic nature that they can quickly dispose of their holdings. Where it is necessary to have the company build its own houses for the community the situation should be handled in such a way that there is no suspicion of patronization.

The specific facilities are not as important as the spirit in which the employer acts. It is human nature, particularly in a democratic country, to prefer inadequate facilities where we feel free from the taint of patronization to adequate facilities which we procure at the cost of being patronized. Normal human beings do not want things done for them. What they desire is an opportunity to do things for themselves. In connection with adult education particularly, care must be taken, as has so often been pointed out, that so-called Americanization work is not conducted in a manner to build up resistances. If properly led, foreignborn groups will take care of themselves. Anything that suggests discredited "welfare" methods should be avoided.

This is not the place to discuss the relation of the employer to his internal organization but it is of course patent that the end in view-a democratic upstanding local community-cannot be developed unless the internal conditions of the particular industry are sound. Adequate wages, or at least as adequate as possible, reasonable hours of work, a certain amount of security, a voice in determining wages and working conditions through works councils or conference committees, proper upgrading and training systems which serve to make the job a career, modern and well-worked-out personnel administration, in short, everything that goes to make for esprit de corps reflects itself in the life of the particular community in which the industry is located. What the relation to trade-unionism should be depends upon the particular circumstances. This is not the place for an extended discussion of this question. Suffice it to say that employers should approach this question in an unbiased, open-minded spirit, which, unfortunately, too many of them have lacked.

Thus far we have discussed the opportunities of constructive leadership that are afforded to employers, the chance to do big things in improving the social fabric. This is the side of the relations of the employer to a community that I would like to stress. But there is another side to these relations which must be viewed, and that is those things which the employer must not do.

\section{Respect for Individual Rights}

Just because the employer has power and influence which are extra-political, he must be scrupulous not to exercise it 
so as to impinge upon the political rights of the individual. As an AngloSaxon nation we are jealous of these rights. In the interests of efficiency we have given a grant of power to the individual producer and adopted a more or less laissez-faire policy. But, on the other hand, we are determined that efficiency does not go so far as to endanger the political rights of the individual. In using the term "political rights" I include, of course, the right to join and assist in the organization of trade unions. It is essential that not only must these rights be preserved but there must not even be a remote feeling that there is any tendency to coerce or dominate. This principle is particularly true of the relation of the employer to the local as distinguished from the larger community. I am not here referring to gross violations of these rights involving the use of physical coercion. Nor am I referring to any attempt to interfere with free speech or free assemblage by the improper use of local authority. It seems superfluous to comment on such flagrant and indecent transgressions of the spirit and the letter of our institutions. Aside from its inherent viciousness, the instigation or countenancing of such methods on the part of men supposed to be leaders, lays the foundation for general disregard of law and order. In spite of the wide publicity they receive, such violations are, I think, rare in proportion to the great bulk of our industrial activity. I am referring to more subtle and indirect infractions.

Closely akin to this duty of employers not to encroach upon the political rights of the individual is their duty not to infringe on the social freedom of a community or of their employees. It is of course perfectly proper for an employer, and in fact his duty, to exercise his influence in an open manner and to attempt to create a common-sense point of view in various matters. A "hands-off" policy is undesirable as I have indicated above. He must be careful, however, not to create the impression that he is trying to take advantage of his position.

As a business man, I realize the difficulties that must be faced by any enterprise in its relation to the local community. There are often demagogic and other influences which attempt to stir up trouble for an undertaking that has every right to be protected, but the fact that there are difficulties to be faced is no reason for acting in a tactless, arrogant spirit. Any modern employer conscious of the spirit of the times-conscious that feudalism is a thing of the past-will be able to act as a real leader of affairs in his community. If the community once realizes that no attempt at paternalism is made, it is comparatively easy to obtain its respect and loyalty.

And here let me suggest that the deleterious effect of capitalistic exploitation as such, upon individual and social life, is largely a figment of the imagination of those who have stressed this view. Even where conditions are unfavorable and the management has been harsh and unprogressive, life in a backward farming community is raised by the introduction of industry. I have one particular incident in mind where a "hill-billy" from a West Virginia town where abuses of various kinds existed, even though he complained of the unfair methods used by the employing groups, testified to the great improvement to his personal development that had been brought about by the opportunity afforded him.

In any event, where the management has been progressive and alive to its opportunity for leadership, the standard of the community is often raised to a very marked degree. As a graphic example I might mention a certain 
community which has been established in a locality where there was formerly only very sparse farming. The entire community has been developed and improved socially and morally. This particular industry from the beginning has only paid about 3 per cent on capital to the stockholders but has paid $\$ 22,000,000$ in wages over a period of 22 years. In this particular community there has been built up a real feeling of loyalty to the company but the relation is not a feudal one. There has been no suspicion of patronization. The company has been careful to respect the sensibilities, social, political and otherwise, of the people in the community. The result is an upstanding community and a sound situation for the company generally.
To sum up the preceding discussion, the relation of the employer to the community is of a dual nature. There is an affirmative side in the opportunity afforded of acting as a center of activity in the moral, social and cultural development of the country. There is a negative side in the obligation not to use the power inherent in his position so as to encroach upon the sphere of political rights of the individual. In both phases the exercise of tact and imagination is an essential element.

Unfortunately there are far too few employers who follow these principles, though it is impossible to make a quantitative estimate. What we need here, as elsewhere, is a process of employers' education. 